\title{
CONFUCIANISM, BUDDHISM, AND VIRTUE ETHICS
}

\section{BRADFORD COKELET}

University of Miami

\begin{abstract}
Are Confucian and Buddhist ethical views closer to Kantian, Consequentialist, or Virtue Ethical ones? How can such comparisons shed light on the unique aspects of Confucian and Buddhist views? Oriented by these questions, this essay tackles three tasks: provides a historically grounded framework for distinguishing western ethical theories, identifies a series of questions that we can ask in order to clarify the philosophic accounts of ethical motivation embedded in the Buddhist and Confucian traditions, and critiques Lee Ming-huei's claim that Confucianism is closer to Kantianism than virtue ethics and Charles Goodman's claim that Buddhism is closer to Consequentialism than Virtue Ethics.
\end{abstract}

\section{INTRODUCTION}

Like ancient Greek dialogues and treatises, Confucian and Buddhist texts contain views and concepts that are appealing, but hard to understand and assess. They were, of course, composed in foreign linguistic and cultural contexts, but even if we can overcome those barriers, few historical texts develop arguments and theories in the ways that contemporary philosophers do. Consequently, western-trained moral philosophers who realize that these texts have philosophically interesting and important ideas embedded in them are usually tempted to view them through the lens of contemporary theory. By doing so, we presumably hope to clarify and assess the philosophic views the underlie Confucian and Buddhist texts. More ambitiously, we can hope to find novel views that we will want to appropriate or endorse. 
Now in viewing Confucian and Buddhist texts through the lens of western theory, we must be wary of the ways that western presuppositions can distort our perception, ${ }^{1}$ and resist any temptation to emphasize how western views are better than Confucian and Buddhist ones. If we can avoid these pitfalls, then cross-cultural inquiry and comparison can be a fruitful enterprise. Ideally, it will allow us to acknowledge background assumptions that hold sway in western thinking and thereby enjoy what Hans-Georg Gadamer's calls Hegelian experience - an interpretive experience that teaches us to question our unacknowledged background assumptions and thereby transforms our possibilities for thinking about how to live. ${ }^{2}$

As someone trained in western philosophy but long interested in Buddhist and Confucian thought, I think this is a goal worth aiming for, and I have been excited by the on-going discussions about whether Confucian and Buddhist views are more like Kantian, Aristotelian, and Consequentialist ones. I think that these are just the sorts of cross-cultural questions that can help us appreciate the unique features of Confucian and Buddhist views. To fruitfully pursue comparative questions, however, we need to start with a firm, shared understanding of different types of western ethical theory, and I worry that recent debate has been hampered by a lack of such shared understanding. With this worry in mind, this essay offers a substantive framework for contrasting western ethical theories and explores its implications for recent comparative claims. Specifically, I provide a framework for distinguishing western conceptions of ethics and then critically discuss two comparative claims: Lee Ming-huei's claim that Confucianism is closer to Kantianism than virtue ethics, and Charles Goodman's claim that Buddhism is closer to Consequentialism than virtue ethics. However, before proceeding, I want to pause and consider some skeptical worries that have been raised about the value of comparative work.

\section{IS COMPARATIVE WORK TENABLE?}

In their bracing article "Were the Early Confucians Virtuous?" Roger Ames and Henry Rosemont Jr argue that it is unwise to view Confucian

\footnotetext{
${ }^{1}$ See Dale S. Wright's Philosophic Meditations on Zen Buddhism for discussion about how Buddhism was misunderstood when read through the lens of Romanticism, and an interesting discussion of cross-cultural hermeneutics.

${ }^{2}$ Gadamer, Truth and Method, pp. 346-362.
} 
ethical texts through the lens of western theory. Their argument proceeds in two steps. First, they argue that the type of philosophic reflection that we find in Confucian texts is fundamentally different from, and better than, the dominant form of philosophic theorization found in the west. Second, they argue that because Confucian philosophic reflection is better than western theorizing, we should simply abandon western views and adopt a new, broadly Confucian approach that they call role-ethics. According to Ames and Rosemont, cross-cultural comparisons are at best a waste of time.

To assess their case for role ethics, we can usefully distinguish three lines of argument that Ames and Rosemont weave together. The first focuses on the topics that Confucians discuss: Ames and Rosemont helpfully point out various specific ways in which western and Confucian views of human excellence differ because they focus on different ethical examples and topics. For example, they claim that while western ethical thought centrally focuses on questions about the value and virtue of abstract individuals, Confucian thought focuses on questions about the excellence of concrete, socially-embedded people who are enacting specific roles and the value of the communities, relationships, and modes of experience that these people collectively generate. There may be some truth to this as a broad stereotypical generalization but a western theorist can just agree with Ames and Rosemont and call for more theoretical work to focus on roles, relationships, the ways that social and cultural forces affect people's character, and so forth. If the call to develop roleethics is just a call to focus more attention on roles and other related topics that Confucians discuss, then there is no reason to think that roleethics should be fundamentally different from extant western ethical theory. Ames and Rosemont would just be calling attention to a dusty and neglected room in the house of western theory. ${ }^{3}$

There is, however, more to the call for role ethics. While discussing various topical differences, Ames and Rosemont also push their second and third lines of argument: that western ethics presupposes a false view of the individual self and that it deploys a defective methodology for philosophic ethics. I will discuss these in turn.

\footnotetext{
${ }^{3}$ In fact, most of the topics that Ames and Rosemont want philosophers to discuss more are topics that western virtue ethicists and feminist moral philosophers have successfully pushed people to discuss over the past several decades.
} 
The claim that the individual self is a pernicious western invention or myth and that Confucian thinking does without this myth is intriguing, but hard to assess. I think Ames and Rosemont are unhappy about various psychological, social, and cultural pathologies that we could call the pathologies of modern individualism, and while I agree that there are various regrettable features of modern western life that we could aptly describe in that way, I also have trouble seeing how the relevant psychological, social, and cultural phenomena are rooted in philosophical views about our being individual selves. To make headway here, we would need to tease apart various strands of individualism, discuss whether they are pathological or not, and figure out how and why various specific presuppositions about our being individual selves might leave us subject to pathological individualism. ${ }^{4}$ This not a task I can fully tackle here, of course, but I can briefly discuss two of the main presuppositions about our being individual selves that Ames and Rosemont target.

First, and most basically, there is the idea that we are individuals who exist at different times and in different role-contexts, who are the bearers of mental states, and who have individual self-conceptions. ${ }^{5}$ Following Ivanhoe (2008: 7-12), I take it that Confucians do presuppose that we are individual selves in this sense. For example, Confucians seem to regularly make evaluative judgments of people's motives and intentions. And they also seem to judge people's general character, which is manifest in different role-contexts, and to deploy abstract concepts in these judgments (e.g. Ren seems to be a concept that is used to abstract from excellence in fulfilling specific roles well and to form a more general judgment). Of course the background assumption that we are individuals who exist at different times may have been put into question as Buddhist ideas influenced the later Confucian tradition, but there seems to be little reason to read any such skepticism into the tradition as a whole.

${ }^{4}$ Charles Taylor's Sources of the Self would provide an interesting background against which to assess Ames and Rosemont's overall argument because he nicely distinguishes different conceptions of the individual and different forms of modern individualism (some bad, some good, and some the best of a bad lot), and he is sensibly skeptical about whether we can or should reject all of the things that give rise to modern individualism.

${ }^{5}$ Ames and Rosemont (2011:33) argue that, "just as we might be skeptical of positing the existence of some ontological ground - God, substance, and so on as the "soul" of the totality - so too can we question whether we need to posit an individual self (nature, soul, person, character) behind the many roles we live." 
Finally, like Ivanhoe, I have trouble seeing how conceiving of ourselves as individuals with mental states and with traits that are manifest across various role contexts has to encourage pathological individualism. ${ }^{6}$

Second, Ames and Rosemont argue that, unlike most western philosophers, Confucians never claim that individuals have moral value or rights in virtue of some special, non-socially understood feature or property they have. ${ }^{7}$ To see that this is a common theme in western ethics, consider the Kantian view that rational agents have a special dignity that is grounded in their humanity, and the Utilitarian view that all animals deserve moral consideration in virtue of their sentience. Now neither humanity nor sentience is a social feature that results from virtuous enculturation into roles and relationships, so these theories do claim that individuals have moral value or rights in virtue of some special, nonsocially understood feature or property they have. So if Confucians do not make analogous claims, that is indeed an interesting fact.

There are, however, two problems with the claim that, thankfully, Confucians avoid positing non-social bases of individual rights or moral significance. First, it is hard to see why this sort of individualist view of basic ethical value, which is embedded in many progressive socialpolitical movements in the west, supports pathological individualism. Pace Ames and Rosemont, ${ }^{8}$ individualist views of basic ethical value are completely compatible with philosophic opposition to pathological forms of psychological, cultural, and political individualism. We can accept, for example, that all sentient creatures deserve basic ethical consideration in virtue of their sentience and also hold that it is ethically essential, perhaps even more important, to recognize the great value of fulfilling roles well and achieving virtuous social comportment and community. In addition, we can contend that healthy self-understandings or self-conceptions are fundamentally rooted in social factors, and that respect for persons therefore requires respect for good roles, relationships, and communities. In short, we can simply supplement individualist views about basic moral value or rights with "anti-individualist" ethical views that recognize the importance of roles, virtuous communities, and so forth.

${ }^{6}$ Cf. Ivanhoe on the independence of Ren from specific role concepts like Good Son as he point out, we presumably need some kind of independence to get social critique going.

${ }^{7}$ Ames and Rosemont (2011: 27)

${ }^{8}$ Ames and Rosemont (2011:27-28) 
Next, we should note that some contemporary Confucians explicitly endorse the idea that individuals have basic ethical value or moral rights in virtue of their special, non-socially understood features. In particular, Kantian interpretations of Confucianism take this line when they argue that the four sprouts (of compassion, shame, deference, and knowledge of right and wrong) ${ }^{9}$ are essential human psychological features that provide a priori access to culturally transcendent moral truths and that this grounds a Confucian account of moral autonomy. ${ }^{10}$ The suggestion that this sort of autonomy grounds the moral value or rights of individuals shows up, for example, in Lee Ming-huei's "personalist" approach to political philosophy. Roughly put, Lee holds that all individuals have a special moral value in virtue of the fact that they have the four sprouts and that good institutions are those that enable people to develop these sprouts in ways suggested by the later Confucian tradition. ${ }^{11}$ So there is certainly plenty of room to argue that Confucian and western ethical views are closer here than Ames and Rosemont suggest.

On the basis of these points, I tentatively conclude that neither western assumptions about individual selves nor topical differences in ethical reflection bar the way to useful cross-cultural comparison. This leaves me with the third and final strand of argument that I see in Ames and Rosemont, namely their attack on the common aims and methods of western ethics. Regarding aims, I see them as making two points. First, while western ethicists typically aim to help people think and talk more clearly and coherently about ethics, Confucians aim to help people become more self-reflective and to inspire them to improve. ${ }^{12}$ Second, while western ethical reflection aspires to knowledge of trans-cultural and trans-situational moral or ethical truths, Confucian reflection focuses

${ }^{9}$ Lee calls these "the four buddings".

10 This general line of interpretation is descended from Wang Yang-ming and his incorporation of the Buddhist idea of original Buddha-nature/inherent enlightenment, which was in turn picked up and developed by Mou Zongsan and, later, Lee Ming-huei. My understanding of this tradition is indebted to exchanges with P. J. Ivanhoe.

${ }^{11} \mathrm{My}$ understanding of Lee's political philosophy comes from Elstein (2014: Chapter 5). In the communitarian-liberal part of the chapter Elstein seems to expresses confusion about what the transcendent part of Lee's story is. Presumably it is the four sprouts, which as Elstein himself nicely points out earlier in his chapter, Lee takes to be a priori and culturally transcendent. Of course Elstein could come back and ask how to develop those sprouts, whether they have inherent standards for mature development, and how developed sprouts will lead to specific critiques of standing norms.

12 Ames and Rosemont (2011: 20) 
on developing local, pragmatically useful forms of understanding and appreciation. ${ }^{13}$ In addition, they offer a pair of related methodological contrasts. First, they claim that while western ethics makes central use of abstract concepts such as virtue and autonomy, Confucian thought sticks with more concrete concepts such as mother and prince. ${ }^{14}$ Second, they claim that while western ethics focuses on giving reasons, developing theories, and assessing arguments, Confucian ethics focuses on providing an insightful and inspiring phenomenological vision to guide people. ${ }^{15}$

Something rings true when we consider these contrasts in the light of contemporary academic philosophy. Most moral philosophers do focus on arguments, reasons, and theories, and they tend to work to systematically deploy well-defined abstract terms instead of developing rich phenomenological accounts of concrete situations. Moreover, while their aims are more diverse than Ames and Rosemont suggest, few academic moral philosophers focus their efforts on improving their readers' moral character and edifying moral philosophy is not highly valued in the academy.

So if they do not primarily aim to edify readers, what alternative ends are contemporary moral philosophers pursuing? There are various answers to this question, but three main aims stand out. First, some conceive of moral philosophy as a broadly theoretical endeavor; they aim to understand the fundamental structure of moral reality or to understand morality in all of its linguistic, psychological, social-cultural, and political dimensions. Second, there are those who pursue coherent and well-founded ethical thought because they want to improve public debate about the Right or Good; they hope that the collective efforts of moral philosophers will feed into political processes or debates in the public sphere and lend legitimacy to democratic processes. Finally, third, there are moral philosophers who focus on reasoning, arguments, and theories because they think this sort of rational reflection is collectively conducive to living well, freely, or morally. For example, they may think it will help people answer questions about why they should be moral, or how to think more clearly about the specific moral issues they face.

Given the diversity of aims already animating contemporary moral philosophy, I think we can initially respond to Ames and Rosemont's

\footnotetext{
${ }^{13}$ Ames and Rosemont (2011: 34)

${ }^{14}$ Ames and Rosemont (2011: 18-19)

15 Ames and Rosemont (2011: 20, 34)
} 
methodological critique in roughly the way that we responded to their claims about topical differences. We can simply grant that not enough moral philosophers are in the business of edifying readers and agree that it would be good if more professional philosophers or people trained in philosophy focused on that. ${ }^{16}$ Now I don't know how Ames and Rosemont would respond, but I suspect that they would insist that if and when philosophers take up this aim, they should be prepared to abandon their emphases on rational argument and abstract theorizing and focus more on phenomenological description. In effect this would be to say that philosophers should agree to convert, at least for the purposes of composing edifying work, to something more like Ames and Rosemont's role-ethics.

To assess this suggestion, we need to think a bit more carefully about what edification involves, and the start would be to admit that different ethical views are going to give us different accounts of ethical edification because they presuppose different conceptions of good ethical motivation and human excellence. Since Ames and Rosemont are committed to developing a broadly Confucian view, we should presumably ask whether, given a Confucian ethical view, phenomenological investigation, rational theorization, or both are likely to be conducive to moral or ethical improvement. And to answer that question, we need to first clarify Confucian conceptions of good motivation - for example, their conceptions of good character (Ren) and human excellence (Junzi). So, ironically, I propose that we should make use standard western philosophic methods to understand the nature of the Confucian moral ideal and then assess the suggestion that when we aim to edify, we should abandon standard philosophic methods in favor of the ones that Ames and Rosemont prefer. With that proposal in mind, I turn now to questions about how to compare western ethical theories with Buddhist and Confucian ones and to debates about whether Confucian and Buddhist views are more similar to Aristotelian, Kantian, or Consequentialist ones.

${ }^{16}$ Of course there are exceptions to the generalizations I have been making. Slingerland (2014), Ivanhoe (2013), and Irvine (2013), for example, are recent examples of public edifying philosophy; but as Ames and Rosemont suggest, we could use more work in this vein. 


\section{A FRAMEWORK FOR COMPARISON}

A lot of recent debate about the nature of Buddhist and Confucian ethical views has centered on claims that these views are similar to western forms of virtue ethics, especially Aristotelian virtue ethics. This idea is initially appealing because Buddhism and Confucianism are both ways of life and they involve practices of self-cultivation or character transformation that aim to make us better human beings. Western philosophy, on the other hand, has not been substantively connected to a way of life for some time,${ }^{17}$ but ancient Greek and Roman philosophies were ways of life and they also centrally involved practices of self-cultivation or character transformation that aimed to make people better human beings; ${ }^{18}$ so there is a natural appeal to comparisons of Buddhist, Confucian, and western Classical ideas. In addition, Buddhist and Confucian texts, like Greek and Roman ones, discuss the good traits and states that various practices are meant to inculcate, and they discuss various bad traits and states that the practices are designed to overcome. So we can rightly conclude that the Buddhist and Confucian traditions presuppose and discuss various conceptions of human virtue that we might fruitfully compare with ancient Greek and Roman conceptions.

This train of thought is compelling, and there are good reasons to compare these traditions if we are interested in thinking about what it would be like to pursue philosophy as a way of life, but we should not confuse that claim with the superficially similar claim that Buddhist and Confucian ethical views are more similar to Greek or Roman ones, than, for example, contemporary Kantian ones. More generally, we cannot conclude that Buddhist or Confucian texts presuppose a philosophic understanding of ethics that is closer to Aristotle or the Stoics than to Kant or contemporary Consequentialists from the fact that Confucians and Buddhists focus a lot of attention on virtue and character development. This inference is blocked because Kantians and Consequentialists can and do provide accounts of virtue and specific virtues and vices. In fact, thanks to the virtue ethics movement in $20^{\text {th }}$ century moral philosophy,

${ }^{17}$ This shift is reflected in the evidence that professional ethicists are not especially ethical provided by Schwitzgebel (2013). In my view, that evidence is unsurprising, given the non-edifying aims of professional philosophers, which were canvased in the last section, and the fact that academic philosophy is no longer regularly connected to philosophic communities and practices of self-cultivation.

${ }^{18}$ Interesting discussions of ancient practices of self-cultivation and the idea that ancient philosophers were pursing ways of life include Hadot (1995) and Sellars (2009). 
just about all contemporary moral philosophers recognize that an adequate ethical theory should have what we can call a virtue module. So the mere fact that Buddhists and Confucians presuppose or develop virtue modules of their own tells us nothing about their distinctive moral philosophies.

What we need to make headway at this point is a framework for comparing philosophic accounts of morality, preferably one that allows us to highlight the differences between the accounts of virtue that have been given by Aristotelians, Kantians, and Consequentialists. To begin, I suggest that we follow T. M. Scanlon $(1982,1992,1995)$ and distinguish between philosophic conceptions of morality and the firstorder normative judgments that they support. A philosophic conception of morality identifies some primitive or fundamental evaluative facts and then provides an account of good moral or ethical motivation by appeal to those facts. First-order normative judgments, on the other hand, determine whether specific actions or activities are good or required.

In the most straightforward instance, a philosophic conception will picture well-motivated agents as being in some way directly responsive to the fundamental evaluative facts, but there are also indirect conceptions, which identify well-motivated agents as the ones that we should approve of given full knowledge of the fundamental evaluative facts. For example welfarists hold that the only fundamental evaluative facts are facts about welfare - facts about what makes living things better or worse off. A directagency welfarist pictures good ethical agents as people who register and respond well to the facts about welfare in their environment, presumably by promoting and valuing improvements in the lives of living things and impeding and disvaluing harm to living things. ${ }^{19}$ But an indirect-agency welfarist identifies a well-motivated agent by comparing the different ways in which people could be motivated and picking the one that would best promote the welfare of living beings and impede their being harmed. It might turn out, for example, that the relevant sort of agent is mainly motivated by the divine commands outlined in some religion and that he or she only sometimes notices and directly responds to facts about how living beings are faring.

The distinction between direct-agency and indirect-agency welfarists illustrates that we cannot figure out what philosophic conception

${ }^{19}$ Not all welfarists accept that we should promote maximal overall welfare. Kraut (2009), for example, defends direct welfarism but rejects that idea. 
of morality someone is operating with just by learning about the conception of a well-motivated agent that they endorse. One person can endorse a divine command conception of good moral motivation on indirect welfarist grounds, while another endorses it because she thinks that divine commands are among the fundamental evaluative facts and that a well-motivated agent is directly responsive to them. Similarly, we cannot move from first-order facts about the actions or policies that someone considers good or required to conclusions about their philosophic conception of morality. Kant and Scanlon, for example, each reject welfarism and hold that good moral motivation involves direct responsiveness to two types of fundamental evaluative facts - facts about welfare and facts about moral rightness and wrongness - but there is dispute about whether their philosophic conceptions of morality support or undermine first order Utilitarian claims, e.g. the claim that we are required sacrifice the few to save the many. ${ }^{20}$

With these general remarks as background, let us turn to virtue ethics and the best way to understand the difference between Kantian, Aristotelian, and Consequentialist conceptions of virtue. To begin, we can usefully consider Lee Ming-huei's recent attack on virtue ethical interpretations of Confucianism. Lee rejects all such interpretations and argues that Confucianism is best understood as a deontological view that is similar to Kant's. His overall argument is framed by a distinction between deontological and teleological conceptions that is influenced by Kant and various Kant scholars. Unfortunately, he does not clearly distinguish between fundamental evaluative facts and good motivation in the way we have, but he seems to assume that our conception of good motivation will be direct. Next, he holds that a philosophic conception of ethics is teleological just in case it is welfarist and it is deontological just in case it posits some facts about moral or ethical goodness that are not reducible to facts about welfare. On this scheme, Kant and Scanlon will, plausibly, be classified as deontologists because they insist there are fundamental facts about moral rightness and wrongness that are not reducible to facts about welfare.

With the teleological-deontological distinction in place, Lee expresses puzzlement about how virtue ethics could constitute a third form of

${ }^{20}$ For discussions of whether the philosophic views developed by Kant and Scanlon entail first order Utilitarian views see Cummiskey (1996), Brand-Ballard (2004), and Parfit (2013). 
ethics; he claims that, "because the distinction between teleological and deontological ethics is exhaustive and mutually exclusive, logically it is not possible that there exists a third type of ethics." ${ }^{21}$ Now Lee's puzzlement is understandable because he says that a conception is deontological just in case it rejects welfarism and posits a second, ethical type of fundamental evaluative fact. But we should be wary of describing all theories that posit a second, distinctively ethical kind of good with the word 'deontological'. Doing so implies that all of these theories explain the ethical good by appeal to some fundamental conception of the moral law and that they picture the distinctively ethical evaluative facts as facts about what is morally right and morally wrong or what is moral obligatory and morally forbidden. To see that this is a mistake we need only recall that the virtue ethics movement famously began with calls to abandon those very ways of thinking about the fundamental ethical facts. ${ }^{22}$ By extension, we should expect virtue ethicists who posit a second, distinctively ethical good to reject those deontological strategies for characterizing the ethical good and to pursue some other ones.

To see the need to be careful in carving up philosophic space here, we can usefully turn to Kant's explicit discussion of the issue in the Critique of Practical Reason. At a pivotal moment in that work (5:59-5:62) Kant asserts that any adequate philosophic conception of morality must distinguish between two kinds of good: moral or ethical goodness and welfare (i.e. what is good for someone). His discussion of the distinction is not as clear as one might like, but he says enough to get a rough idea. Concern for prudential good is concern, Kant says, for someone's "wellbeing or woe" (5:60). Concern for ethical or moral goodness on the other hand is concern for what makes people and actions fit targets for ethical emotions. For example, positive emotions such as healthy self-respect, pride, or admiration are fit just in case they respond to ethical goodness and negative emotions such as ethical shame, guilt, resentment, and contempt are fit just in case they respond to ethical badness. More generally, Kant seems to assume that ethical goodness is the kind of goodness that makes things worthy of ethical approval and that ethical badness is the kind of badness that makes things worthy of ethical disapproval. Ethical goodness so understood is clearly different than welfare, because things can be good for us without being ethically good,

${ }^{21}$ Lee (2013: 51)

22 See Anscombe (1958) 
and bad for us without being ethically bad. For example while being in a coma is certainly bad for you - it detracts from your welfare - it does not make you more worthy of ethical disapproval (or approval).

Now after distinguishing the ethical good from welfare, Kant goes on to contrast two ways in which one can understand or explicate the nature of the ethically good. The first approach is to posit some substantive conception of the ethically good and hold that both discernment of the ethical good and motivation by awareness of it depend on one's contingent character or, in Kantian lingo, one's empirical, sensible character. Kant rejects that view as heteronomous and adopts the (second) autonomous view, according to which the criterion of ethical good and evil is supplied by an a priori rational law of willing - an a priori moral law that allows one to discern and be moved to embody good and evil regardless of one's character or experience. Against this backdrop, it is no surprise to find Kant thinking that the fundamental ethical facts, which cannot be reduced to facts about welfare, are facts about what is morally right and morally wrong or what is moral obligatory and morally forbidden.

For our purposes, there is no need to consider Kant's questionable arguments in favor of his deontological conception of the ethical good; it is sufficient to note that Kant himself distinguishes two ways of understanding the ethical good and that only the second is well described as deontological. Only the second, autonomous conception of the ethical good makes use of the concept of a moral law in order to ground our understanding of the ethical good, and that leaves open the possibility that virtue ethicists can offer a third type of view that is neither deontological nor teleological. Put otherwise, Lee is wrong to claim that there are only two kinds of ethical theories, deontological and teleological, and that all theories that recognize the distinction between the ethical good and welfare are deontological. ${ }^{23}$

To make further headway in our thinking about the nature of virtue ethics and questions about whether the philosophic conceptions of ethics presupposed in Confucianism and Buddhism are closer to Kantian

\footnotetext{
${ }^{23}$ Recently Kant scholars have discussed whether Kant's theory should be called teleological because of the central role it assigns to the ethical good. Of course we can use technical terminology however we want, but in line with my discussion of Lee's framework I would favor calling Kant's theory deontological because he thinks we should use the idea of an a priori moral-rational law in order to understand the ethical good. Cf. Reath (2003: section II) for a related discussion of Paul Guyer's teleological interpretation of Kant.
} 
deontology or Aristotle's view, I will now take a closer look at how Kantian and Aristotelian views differ. In short, I believe that Aristotle distinguishes the ethical good from welfare in just the way Kant insists any plausible theory must and that his philosophic conception of ethics shows us how to develop a non-deontological, virtue ethical alternative to welfarism. I should admit at the outset that historical interpretation is a tricky and contested business and that I will be presenting a speculative reconstruction of Aristotle's view, not a detailed exegetical argument. With that said, I now claim that Aristotle explicitly distinguishes between ethical goodness and welfare just like Kant. Specifically, at Nicomachean Ethics 1104b31, Aristotle distinguishes three types of good - the noble, the advantageous, and the pleasant - and Aristotle's nobility (ta kalon) is a distinctively ethical kind of goodness that makes people and activities worthy of ethical approval. By extension, I think we can understand Aristotle's famous example of a virtuous man choosing to sacrifice his life in order to protect his city as an example of someone who chooses the ethical good (acting virtuously) over his prudential good (staying alive). ${ }^{24}$ More generally, Aristotle holds that true nobility is a great ethical good and that good motivation involves direct responsiveness to this good and not just facts about welfare and pleasure; on his view, I suggest, rational discernment of the ethical good structures and guides the practical agency of a virtuous person, and this enables him to embody ta kalon in his activities and interactions with others. ${ }^{25}$

Now given this reading of Aristotle, he and Kant make analogous distinctions between ethical goodness and welfare and they also seem

\footnotetext{
${ }^{24}$ The Greek word translated as 'advantageous' is sumpheron not eudaimonia, and the Latin utilitas is derived from sumpheron, so it seems plausible to think that Aristotle's concept of advantage is close to Kant's concept of well-being. As Engstom (1998), explains, the concept of the highest good is the closest thing in Kant's system to Aristotle's eudaimonia. Thanks to Matt Walker for helping me with the Greek.

${ }^{25}$ The suggested reading of Aristotle is no doubt contentious, and a welfarist could point out that the virtuous person who sacrifices himself does so in order to promote the (common) good of the city. I agree, but think that when Aristotle says the virtuous person acts for the sake of the noble, this implies that he would sacrifice himself for the common good because doing so is noble or fine. Kraut (ms.) carefully discusses relevant Aristotelian texts and argues, roughly, that the value of the noble always "supervenes" on some welfare-based good(s). His view seems compatible with the claims I make in the text, but also with a resolutely welfarist interpretation of Aristotle. Finally, although I don't agree with her principle-based understanding of the noble, my interpretation of Aristotle is indebted to Korsgaard (1996).
} 
to agree that good motivation involves direct, rational responsiveness to the value of ethical goodness, but their specific conceptions of ethical goodness, rational responsiveness to ethical goodness, and ethical approval are very different. Moreover, I believe that if we attend to these differences we can both see why it makes sense to call Aristotle's view a form of virtue ethics and see how to best approach questions about whether Buddhist and Confucian views are more similar to Aristotle's or Kant's.

First, take their conceptions of ethical goodness. Kant holds that the ethical good is the good will, which acts out of respect for the dignity of the moral law. We can ignore the various hard to understand nuances of Kant's view here and focus on three of its main features. First, he holds that any normal, mature agent can instantiate the ethical good at will. The good will is, we might say, always within volitional reach. Second, Kant thinks that to instantiate the ethical good, one must rationally respond to the inherent dignity that all agents have and that this involves willing for reasons that they could appreciate and rationally endorse. Third, Kant holds that the ethical good is moral and that it therefore does not involve non-moral excellences of character such as wittiness or non-moral personal excellences such as courage in the pursuit of one's projects.

When we turn to Aristotle, we get a very different picture of the ethical good. He holds that the ethical good is ta kalon, often translated as the fine, the noble, or the beautiful. He tells us that virtuous people are those with noble character, who perform virtuous activities in a noble or fine way, and that those activities thereby reflect the agent's rational appreciation of the value of ta kalon. Here again, we can bracket questions about how to understand the nuances of this view, and focus on how it contrasts with Kant's. First, Aristotle locates the ethical good in activities and character traits, not in the will, and he denies that any mature agent can embody the ethical good at will. Aristotelian nobility is not always in volitional reach. Second, Aristotle does not posit any sort of inherent dignity or think that virtue requires acting for reasons that all rational agents can appreciate. On the contrary, he thinks that the virtuous can appreciate aspects of the fine that vicious or base people cannot, and that they will therefore act for reasons that the base cannot appreciate or endorse. Finally, third, nobility is not restricted to the moral domain and it does involve non-moral (e.g. aesthetic) excellences of character such 
as wittiness and non-moral personal excellences such as courage in the pursuit of one's projects.

Next, we can contrast Aristotelian and Kantian conceptions of rational responsiveness to the ethical good. As noted, Kant and Aristotle disagree about whether any mature agent is capable of rational discernment and embodiment of the ethical good, and this shows up in three more specific ways. First, Kant thinks we can discern and rationally respond to the value of the ethical good regardless of our contingent emotional dispositions, while Aristotle thinks we need to have virtuous emotional dispositions in order to discern and respond to the ethical good. Second, Kant thinks we can have a conflicted psychology but still discern and embody the ethical good, but Aristotle denies this. On his view, one needs a relatively harmonious psychology in order to discern and rationally respond to the ethical good. Finally, third, Aristotle thinks one needs a good upbringing and instruction in order to discern and embody the ethical good, while Kant is more egalitarian and thinks even those who are poorly raised and uncultivated can discern and embody the ethical good. ${ }^{26}$

Now to see why it makes sense to describe Aristotle's view as a form of virtue ethics, it will help to say something brief about Kant's theory of virtue. Given common misconceptions, the first thing to emphasize is that Kant does have a conception of virtue and that he says quite a bit about virtue and the development of character (e.g. good emotions and traits). The second thing to say, though, is that virtue plays a decidedly secondary role in Kant's ethical theory. He holds that anyone can adopt a good will and that adopting such a will involves adopting various moral ends, one of which is the perfection of one's moral character - roughly one's ability to embody respect for persons and "wide" benevolence.

\footnotetext{
${ }^{26}$ A full comparison would also consider the conceptions of ethical approval and disapproval that Kant and Aristotle adopt. Kant holds that people of good will merit respect and self-contentment and that people with evil wills merit guilt and resentment. When it comes to judging ethical worth, Kant holds that we are all competent to rationally judge our own worth and that we should never rely on others' input or ideals from religious traditions when assessing ourselves. In addition, he argues we should never judge other's worth. Aristotle's views differ on all fronts. He holds that noble agents merit honor, pride, and love and that ethically unworthy agents (with base characters) merit derision and shame. When it comes to judging worth, he holds that noble and virtuous people are better at judging worth than those who are base. Consequently, he holds that the virtuous should go ahead and judge both their own worth and that of others, and that we should allow our assessments of worth to be influenced by the judgments of virtuous friends and teachers, especially if we are ourselves sub-virtuous.
} 
So one's ethical worth will certainly be affected if one does not seriously intend to improve one's character, but Kant nonetheless denies that our ethical worth or the ethical worth of our actions is affected by how virtuous our character is at any time. So while Kant does give an account of moral virtue, understood as a contingent form of character excellence that involves good emotional dispositions and skills, and commends the pursuit of this virtue, he denies that one needs virtue to discern or embody the ethical good or to merit unreserved ethical approval. ${ }^{27}$ Moreover, it is important to emphasize that Kant's conception of virtue is moralized and that Kantian virtue consequently does not contribute to welfare or flourishing in the way that Aristotelian virtue does. Kantian virtue does not require robust psychic harmony, non-moral character excellences, or non-moral personal excellences; some of the central aspects of Aristotelian virtue that presumably contribute to one's welfare. ${ }^{28}$

These observations about Kant's account of virtue highlight the more central role that non-moralized virtue plays in Aristotle's theory and allows us to see why his conception is aptly called virtue ethical. Kant and Aristotle each reject welfarism, posit a distinctively ethical good, and conceive of good ethical motivation as direct responsiveness to the ethical good. But while on Kant's theory neither good moral motivation nor the ethical good are to be explained by an account of virtue, understood as a contingent form of character excellence that involves good emotional dispositions and skills, on Aristotle's theory both the ethical good and good moral motivation are to be explained by appeal to virtue. Moreover, Aristotle's conception of virtue is not moralized, so he thinks that good ethical motivation, which embodies rational responsiveness to the ethical good, involves psychic harmony, non-moral character excellences, and non-moral personal excellences. So perhaps we can best characterize Aristotle's philosophic ethics as a form of non-moralized virtue ethics and characterize Kant's view as

${ }^{27}$ There is a slight complication because Kant sometimes says that the highest good is the concept of a state in which happiness or well-being is proportioned to virtue, and this implies that those with virtuous character are more worthy of happiness and approval than those who have good wills but are only working toward virtue. I think this is an artifact of Kant's loose usage of 'virtue' and that Kant's considered view would be that in the state rightly called the highest good, happiness or well-being is proportioned to moral worth, not virtue, but I also think there is a serious tension in Kant's work here.

${ }^{28}$ Baxley (2010) provides an excellent discussion of Kantian virtue and its compatibility with psychic disharmony. 
deontological (non-virtue ethical) and moralized. ${ }^{29}$

\section{APPLYING THE FRAMEWORK TO CONFUCIANISM}

With this general discussion of philosophic theories in mind, we are in a position to better assess Lee Ming-huei's recent attack on virtue ethical interpretations of Confucian ethics. Lee rejects these interpretations and argues in favor of a Kantian one, but, as we have seen, his arguments rest on the implausible assumption that philosophic conceptions of ethics must be either teleological or deontological. Now that we have a clearer grip on the availability of virtue ethics as a substantive third option, we can see that Lee's first argument in favor of his Kantian interpretation is unsound. This argument, which Angle (2014) calls 'the heterogeneity argument', draws our attention to passages in which Confucians appear to distinguish between the ethical good and welfare. For example, Lee cites Analects 4.16 in which we read, "The Master said, 'The mind of the superior man is conversant with righteousness; the mind of the mean man is conversant with gain."'

In discussing this argument Angle does not attack the background assumption that only deontologists distinguish the ethical good from welfare. Instead, he argues that the translation may be contentious, and that some might reject the idea that Confucius is distinguishing the ethical good from welfare here. ${ }^{30}$ Now I cannot speak to the exegetical issues directly but, in the light of our preceding discussion of Kant and Aristotle, we can simply grant that Confucius is distinguishing two types of good and point out that this shows nothing about whether Confucian thought is more similar to Kant's or Aristotle's. To determine whether Confucius' theory is deontological or virtue ethical, we need to ask whether the Confucian ethical good (Ren) is more similar to Aristotelian nobility (ta kalon) or to the Kantian good will.

${ }^{29}$ Could there be a plausible deontological virtue ethical conception, given the way I am using those terms? Well, Scanlon's view comes close because he thinks of ethical goodness and badness as moral rightness and wrongness but also holds that one needs contingent emotional dispositions to discern and embody the ethical good. But, like Kant, he adopts a moralized conception of virtue. In any case, I think that the hybrid structure of Scanlon's theory actually makes it harder to defend than more resolutely Kantian deontological theories such as Korsgaard's and Darwall's, or more resolutely virtue ethical views.

${ }^{30}$ Angle (2014: 235-236). In footnote 18 Angle mentions that some philosophers might question Lee's framework assumption, but he does not develop this line of response. 
In hope of best advancing debate in this area, I want to start with some general remarks about Lee's overall interpretation of Confucianism and why he thinks Confucianism constitutes an improvement over orthodox Kantianism. On Lee's Confucian view as I currently understand it, ${ }^{31}$ all mature human beings are endowed with the four sprouts: "the dispositions of compassion, of shame and dislike, of yielding and deference, and of discriminating right and wrong" (Lee 2013: 52). These sprouts or "buddings" provide us, Lee contends, with a priori rational access to transcultural values. This view of the four sprouts is modeled on Kant's view that respect is a rational but sentimental form of responsiveness to the moral law, ${ }^{32}$ but it expands the scope of our sentimental rational access to a priori ethical truths. Now despite being originally endowed with these sprouts, not all human beings are well-motivated people (Ren) or excellent human beings (junzi), so we need an account of what it is that a well-motivated person has, over and above the four sprouts, that other people lack, and we also need an account of ethical development or cultivation. In my view the best way to engage with Lee, and to press him to defend his Kantian interpretation over a virtue ethical one, is to focus on those issues.

The contrasts we have drawn between Kant and Aristotle suggest numerous lines of inquiry here. Here are three main ones:

Q1: Is Ren in the volitional reach of all mature human beings because they have the four sprouts? Is good intention/will sufficient for Ren or do we need contingent good character to embody Ren?

Q2: Is Ren moralized? Does it include psychic harmony, non-moral character excellences, or personal character excellences?

Q3: Does Ren involve acting on reasons that cannot be discerned or fully appreciated by less than fully virtuous people? Is possession of the sprouts sufficient for discernment of Ren and motivation by Ren's value? Or does one need contingent good character to appreciate what is Ren and the value of Ren?

Of course I can't pretend to answer these questions here, and I recognize that different Confucian texts and authors may suggest different answers.

\footnotetext{
${ }^{31}$ In addition to Lee (2013), I am relying on the discussions of Mou Zongsan's and Lee's work in Elstein (2014) and Billioud (2011).

${ }^{32}$ See Reath (2009) for debates about how to understand the rational sentiment of respect in Kant.
} 
What I can do is discuss two texts to which Lee appeals in order to support his Kantian, deontological interpretation.

First, Lee appeals to Analects 12.1 in order ground what Angle (2014) calls his 'autonomy argument'. Lee's appeal to this passage might help settle our questions about whether Ren is more like Kant's good will or Aristotle's nobility because it suggests that Ren is something people achieve through their own efforts. More specifically, Lee would presumably contend that Analects 12.1 supports the deontological idea that the ethical good, Ren, is within the volitional reach of normal or mature agents. Here is the passage:

Yen Yuan asked about ren. The Master said, 'To subdue one's self and return to propriety, is ren. If a man can for one day subdue himself and return to ren, the world will turn to ren along with him. To be ren comes from the self; does it then come from others?"

Read closely, however, this passage doesn't seem to support the claim that Confucian Ren is within the volitional reach. It does imply that to achieve Ren one needs to subdue oneself and return to propriety and that these are not things that someone else can do for you, but that does not entail that just anyone can subdue himself, return to propriety, and thereby achieve Ren. At the very least, this effort seems to require strong commitment and perseverance, even for exemplars such as Confucius:

At fifteen, I set my heart on learning. At thirty, I stood firm. At forty, I was free of delusions. At fifty, I understood the Mandate of Heaven. At sixty, my ear was attuned. At seventy, I could follow my heart's desires without overstepping what is proper. (Analects 2.4) ${ }^{33}$

Consider an analogy. In order to perform a beautiful symphony, the musicians may need to subdue themselves and focus on the music, and it might well be that this is not something that others can do for them. But not just any group of people with instruments in their hands can subdue themselves and return to the music and thereby produce a beautiful symphony. People who are easily distracted, lack a discerning ear, or lack musical training will not be able to pull it off; having a manageable mind, discerning ear, and musical training are all necessary background conditions that enable good musicians to produce beautiful music by subduing themselves and focusing on the music. By analogy, although

${ }^{33}$ Thanks to PJ Ivanhoe and an anonymous reviewer for suggesting the relevance of this text. 
Analects 12.1 suggests that autonomous effort is necessary for achieving Ren, it need not suggest that such effort is sufficient. Achieving Ren may require subduing oneself and returning to propriety oneself but it may also require contingent good character and experience as background enabling factors, and this is just what a virtue ethical view would predict. ${ }^{34}$

We have just seen that Analects 12.1 need not be read in a deontological way, and that it therefore does not support Lee's Kantian interpretation, but I think a second passage he cites actually tells quite strongly in favor of a virtue ethical reading of the ethical good. The specific passage is Analects 17.21 in which Zai Wo proposes to shorten the mourning period after his parents die and Confucius criticizes him for this. As Lee points out, Zai Wo's rationale seems to be that the shortened mourning period would be good for him - that it would promote his welfare - and Confucius' criticism of Zai Wo implies that a better man would choose the ethical good (Ren) over the prudential good (welfare). Lee naturally takes this to tell in favor of his deontological reading, but at this point in our discussion, we can see the need to focus on what the passage tells us about the nature, not just the existence, of the Confucian ethical good. Here is a pertinent extract:

... a superior man, during the whole period of mourning, does not enjoy pleasant food which he may eat, nor derive pleasure from music which he may hear. He also does not feel at ease, if he is comfortably lodged. Therefore he does not do what you propose. But now you feel at ease and may do it.

Now as Slingerland (2001) and Angle (2013) discuss, one might think this passage suggests a virtue ethical conception, not a Kantian, deontological one because, while the ethical good (Ren) is pictured here as involving feeling, Kant is often thought to associate the ethical good with reason and duty, not feeling and inclination. In response, Lee could make two points. First, as Angle suggests ${ }^{35}$, he could point to the fact that Kant has a theory of virtue; Kant thinks that a person with an ethically good will necessarily intends to improve her empirical character, including her

${ }^{34}$ As Ames and Rosemont (2013: 21) indicate, some passages also suggest that the presence of cultural exemplars is a relevant necessary enabling factor. For example, they point to Analects 5.3: “The Master remarked about Zijian, 'He is truly and exemplary person. If the state of Lu had not other exemplary persons, where could he had gotten this from?"'

${ }^{35}$ Angle (2013: 240-241) 
inclinations and dispositions to feel. Second, Lee could point out that on his view Confucian Kantianism improves on the original precisely by broadening the scope of the rational sentiments; while Kant recognizes reason only in the way that respect for the law strikes down self-conceit, Confucian Kantians recognize reason in all four of the sprouts, which give humans a priori access to the moral truth. So it is a serious mistake to assume that Confucian Kantians associate the ethical good with reason and duty, not feeling and inclination.

Despite the foregoing points about the role of reason and feeling in Kantian Confucianism, I still think that Analects 17.21 supports a virtue ethical understanding of the Confucian ethical good. To see why, notice two points. First, in the passage quoted above, the difference between the superior man and Zai Wo hinges on what they take pleasure in and what they feel comfortable doing, and these are not factors that are reliably under people's volitional control. Kantians do characteristically hold that the ethical good requires intending to improve such factors, but they deny that our worth depends on our success. In the passage, however, Confucius is apparently expressing ethical approval of the person because he has one sort of empirical character instead of another, so this passage tells in favor of a virtue ethical reading. Second, notice that at the end of the passage Confucius says that because of his poorer character, e.g. his disposition to enjoy food and drink during part of the mourning period, Zai Wo should go ahead with his proposal and shorten his mourning period. This implies that if Zai Wo had better character and could embody the ethical good by upholding the customary mourning period, then he should do that, but that since the ethical good is not within his volitional reach, he might as well choose the (ethically subpar) option that is least costly to his welfare. This, again, does not sit well with a Kantian understanding of the ethical good.

To buttress the claim that Analects 17.21 suggests a virtue ethical understanding of the Confucian ethical good, rather than a deontological Kantian one, we can helpfully reflect on the deontological idea that the ethical good involves willfully living up to a moral law. Talk of a moral law implies that someone has the authority to demand that you live up to it and that you should feel guilty if you fail to do so. Moreover, as Darwall (2006) has recently emphasized, those facts support the view that if you are subject to a moral law, then you can live up to it by holding yourself responsible for doing so; if you are subject to a moral law, then compliance is within your volitional reach. Now turn back to Confucius 
and Zai Wo. If Zai Wo cuts short his mourning period, as Confucius encourages him to do, then he fails to embody the ethical good (Ren). If Zai Wo were, however, subject to a moral law demanding that one embody Ren, then being Ren would be in his volitional reach and Confucius' recommendation would be vicious. If Ren were grounded in a moral law in the way that is characteristic of Kantian deontology, then Confucius should have told Zai Wo to stick to the customary period out of respect for the law and intend to cultivate better character. Moreover, Confucius should have expressed just as much ethical approval for that version of Zai Wo as for someone who exhibits psychic harmony during the mourning period, i.e. someone who is not pained by forgoing music and food during the mourning period. ${ }^{36}$ But this Kantian Confucius is not the one we find in Analects 17.21. I suspect it is not one we find elsewhere in the Confucian cannon either, but I will be happy to be corrected as I learn more about various Confucian views; my aim here has only been to clarify how Lee and his Anglophone critics might more fruitfully debate whether Confucianism is best understood as a form of deontology or virtue ethics, and I hope the framework I have given can do that.

\section{APPLYING THE FRAMEWORK TO BUDDHISM}

In this short, final section, I want to shift gears and begin to apply the framework we have developed to debates about the nature of Buddhist Ethics. In particular, I want to hone in on Charles Goodman's attack on virtue ethical interpretations of Buddhism and his contention that Buddhist ethics is best understood as a form of Consequentialism. We have not previously explicitly discussed Consequentialism and it is a doctrine that comes in numerous varieties, but the rough idea is that people's actions, intentions, and characters should be ethically evaluated based on the consequences that they actually produce, they could be reasonably be expected to produce, or that they generally tend to produce. The relevant consequences are usually conceived of as outcome states states of affairs, philosophers say - and they can be evaluated according

${ }^{36}$ Of course Lee could also appeal to the four sprouts to fill out this story, but I don't see how this could undercut the main point. If the basic sprouts are sufficient for being able to embody Ren and Ren requires acting out of good character, then it is hard to believe that all humans have the four sprouts. 
to a variety of evaluative schemes. For simplicities' sake we can stick with an impartial welfarism-maximizing form of consequentialism according to which intentions, motivations, and characters are ethically good if they produce, or generally tend to produce, overall welfare increases (impartially weighed), and that they are ethically bad if they produce, or generally tend to produce, woe (impartially weighed). On this view, virtue ethicists and Kantians are both wrong to posit two fundamental kinds of good and to then picture good ethical agency or character as some sort of direct responsiveness to these goods. On the contrary, our consequentialists argue, only facts about what is good or bad for living things are fundamental and an ethically well-motivated agent is just one whose agency or character either directly or indirectly promotes a better world, measured in welfare terms.

With this rough characterization of welfare consequentialism in hand, we can turn to one of Goodman's main arguments that Buddhism is best understood as a form of consequentialism, rather than a form of virtue ethics. Specifically, consider this claim:

Strongly Altruistic Agent: Mahayana and Vajrayana saints are radically impartial and altruistic but Aristotle's virtuous agent is not, so Mahayana and Vajrayana ethics do not fit well with Aristotelian virtue theories.

This claim captures one main line of argument in Goodman's book, Consequences of Compassion. He gives numerous examples of Buddhist texts recommending that we act so as to bring about the most welfare or that we admire people who sacrifice themselves in order to benefit others; but our discussion of philosophic conceptions of ethics at the start of section III casts doubt on the idea that these first order normative views and views about the nature of good ethical agency or character show that Buddhist ethics is a form of philosophic consequentialism. As mentioned in section III, a philosophic conception of ethics identifies some primitive or fundamental evaluative facts and then provides an account of good moral or ethical motivation by appeal to those facts, but philosophers with very different views of the fundamental evaluative facts can embrace similar or identical views of good agency or first order views about which actions are required or good. For example, there is no reason at the outset to doubt that someone could embrace either a Kantian deontological or neo-Aristotelian virtue ethical conception of the fundamental evaluative facts and also hold that a well-motivated 
agent who directly responds to the fundamental facts will embody radical impartiality or altruism at the first order level.

To move beyond a bare challenge to Goodman here, we can usefully consider Aristotle's function argument and the possibility that it grounds Aristotle's conception of the ethical good in something like the way the moral law grounds Kant's. On this view, Aristotle appeals to a background account of human nature or the human condition, uses that to identify a conception of a well-functioning human being, and then uses that to ground his conception of the ethical good (ta Kalon). Roughly, the noble human being deserves ethical approval because he is an admirably functioning human being. Now given this (admittedly contentious) understanding of Aristotle's function argument, we can see how an Aristotelian might be converted to the Buddhist first order ethical view. All we need to do is assume that on some theory of human nature a well-functioning human being will be one who is radically impartial and altruistic. If our Aristotelian comes to accept that theory, then she will agree that it is noble to act like a Buddhist saint and to do so because it is the noble thing to do. Roughly, she will think that to embody the welfare-independent ethical good one must be radically impartial and altruistic.

Interestingly, this basic idea bears at least some resemblance to the views developed in the Tathagatagarbha Buddhist traditions of Tibet and East Asia, which posit an inherent Buddha nature or potential. Perhaps this tradition would provide a strong analogue to Aristotelianism insofar as it would have us identify virtue with the realization of our characteristic potential to become a Buddha. Perhaps we could locate something like a function argument in the texts of this tradition, and perhaps that traditions' influence on later Confucianism would help support a neoAristotelian reading of the Confucian tradition. Once again I have to leave these as further questions to pursue within our framework.

The main point to emphasize at this juncture is that to settle questions about the philosophic nature of Buddhist or Confucian ethics, we need to go beyond the first order ethical views and conceptions of good motivation that are commended in the tradition, and try to figure out why Buddhists commend the views that they do. We need to try to identify the fundamental evaluative facts they posit, not just how they hope people are motivated or act in the light of those facts.

As a closing remark about Buddhism let me add that this task will be especially hard when we turn to Mahayana Buddhist views that endorse 
the doctrine of two truths. Very roughly, these views hold that no conceptually articulated beliefs or views are absolutely true, but that we may well be pragmatically justified in espousing or even holding these beliefs and views if doing so will be beneficial. To see the problem that this view poses for Goodman, we need to note that he interprets Buddhists as holding (i) that there are some fundamental evaluative facts, (ii) that we should try to promote the good ones in maximal and impartial fashion, (iii) and that this we should do so because ordinary beliefs about persons and personal identity - which we ordinarily take to justify partiality - are merely conventional truths to be seen through. The last of these claims, about personal identity, is a good fit with the two truths doctrine; on the relevant Buddhist views, belief in, or claims about, personal identity are conventionally justified but not absolutely true, and insight into their fundamental non-truth is essential to overcoming suffering. The problem for Goodman, however, is that something similar seems to be true of our beliefs about the welfare of living beings being good and pain being bad; these are presumably conventionally justified beliefs, but not true absolutely. And if this is right, we have to ask why Buddhists should take belief in fundamental evaluative facts any more seriously than they take belief in the self. Put otherwise, Goodman seems hold that when engaging in ethical theorizing I should treat personal identity as a conventional view to be seen through because it is merely conventional, but that I shouldn't do the same when it comes to conventional views about welfare or pleasure being intrinsically good. And it is hard to see how to defend such a stance. On the other hand, if we see through all views about the fundamental evaluative facts because they are all merely conventional, then the Buddhist view looks closer to value nihilism than, say, welfarism consequentialism. That is not to say that the view must be false. Perhaps this is just a stark case in which engagement with Confucian and Buddhist views give us a chance to recognize and question background western assumptions about the sorts of philosophic ethical views that we can take seriously. 


\section{BIBLIOGRAPHY}

Ames, Roger T. and Henry Rosemont, Jr., 2011. "Were the Early Confucians Virtuous?", in Chris Fraser, Dan Robins, and Timothy O'Leary, Ethics in Early China: An Anthology (Hong Kong University Press)

Anscombe, Elizabeth. 1958. "Modern Moral Philosophy”, Philosophy 33, No. 124: $1-19$

Angle, Stephen C. 2014. "The Analects and Moral Theory", in Dao Companion to the Analects, edited by Amy Olberding, Dao Companions to Chinese Philosophy, 4 (Netherlands: Springer), pp. 225-57

Aristotle. Nicomachean Ethics. Trans. by Sarah Broadie and Christopher Rowe (Oxford: Oxford University Press, 2002)

Baxley, Anne Margaret. 2010. Kant's Theory of Virtue: The Value of Autocracy (Cambridge: Cambridge University Press)

Billioud, Sébastien. 2011. Thinking Through Confucian Modernity: A Study of Mou Zongsan's Moral Metaphysics. (Leiden: BRILL)

Brand-Ballard, Jeffrey. 2004. "Contractualism and Deontic Restrictions", Ethics 114 (2), 269-300

Elstein, David. 2014. Democracy in Contemporary Confucian Philosophy (London: Routledge)

Engstrom, Stephen. 1996. "Happiness and the Highest Good in Aristotle and Kant," in S. Engstrom and J. Whiting, eds., Aristotle, Kant, and the Stoics (Cambridge: Cambridge University Press), pp. 102-38

Gadamer, Hans-Georg. 2004. Truth and Method, 2nd revised edition (London; New York: Bloomsbury Academic

Goodman, Charles. 2009. Consequences of Compassion: An Interpretation and Defense of Buddhist Ethics (Oxford: Oxford University Press)

Hadot, Pierre. 1995. Philosophy as a Way of Life: Spiritual Exercises from Socrates to Foucault, edited by Arnold Davidson, 1st edition (Malden, MA: WileyBlackwell)

Irvine, William B. 2008. A Guide to the Good Life: The Ancient Art of Stoic Joy (Oxford; New York: Oxford University Press)

Ivanhoe, Philip J. 2008. “The Shade of Confucius: Social Roles, Ethical Theory, and the Self", in Polishing the Chinese Mirror: Essays in Honor of Henry Rosemont, Jr, edited by Marthe Chandler and Ronnie Littlejohn (New York: Global Scholarly Publications), pp. 34-49

Ivanhoe, Philip J. 2013. Confucian Reflections: Ancient Wisdom for Modern Times (London: Routledge)

Kant, Immanuel. 1997 [1788]. Critique of Practical Reason (Cambridge: Cambridge University Press)

Korsgaard, Christine M. 1996. "From Duty and for the Sake of the Noble: Kant and Aristotle on Morally Good Action", in Aristotle, Kant, and the Stoics: 
Rethinking Happiness and Duty, edited by Stephen Engstrom and Jennifer Whiting (Cambridge: Cambridge University Press), pp. 203-236

Kraut, Richard. 2009. What Is Good and Why: The Ethics of Well-Being (Cambridge, Mass.: Harvard University Press)

Kraut, Richard. "Agathon and Sumpheron: Nicomachean Ethics 1094a1-2" (ms.) Lee, Ming-huei. "Confucianism, Kant, and Virtue Ethics", in Stephen Angle and Michael

Slote, eds, Virtue Ethics and Confucianism (NY: Routledge, 2013), pp. 47-55

Reath, Andrews. 2006. "Kant's Theory of Moral Sensibility", reprinted with new notes in Agency and Autonomy in Kant's Moral Theory (Oxford: Oxford University Press)

Reath, Andrews. 2003. "Value and Law in Kant's Moral Theory", Ethics 114, no. 1: $127-55$

Sellars, John. 2009. The Art of Living: The Stoics on the Nature and Function of Philosophy, 2nd edition (London: Bristol Classical Press)

Scanlon, Thomas M. 1982. "Contractualism and Utilitarianism", in Utilitarianism and Beyond, edited by Amartya Kumar Sen and Bernard Arthur Owen Williams (Cambridge: Cambridge University Press), pp. 103-10

Scanlon, Thomas M. 1992. "The Aims and Authority of Moral Theory", Oxford Journal of Legal Studies 12, no. 1: 1-23

Scanlon, Thomas M. 1995. "Moral Theory: Understanding and Disagreement", Philosophy and Phenomenological Research 55, no. 2: 343-56

Schwitzgebel, Eric, and Joshua Rust. 2013. "The Moral Behavior of Ethics Professors: Relationships Among Self-Reported Behavior, Expressed Normative Attitude, and Directly Observed Behavior", Philosophical Psychology, no. 3: 1-35

Slingerland, Edward. 2014. Trying Not to Try: The Art and Science of Spontaneity (New York: Crown, 2014)

Taylor, Charles. 1992. Sources of the Self: The Making of the Modern Identity (Cambridge, Mass: Harvard University Press)

Wright, Dale S. 2000. Philosophical Meditations on Zen Buddhism (Cambridge: Cambridge University Press) 